Received : 20.08.2014.

Reviewed paper

UDK: 373.2 .022

\title{
IMPLICIT THEORIS OF EDUCATORS AND WILLIAM GLASSER'S CHOICE THEORY
}

\author{
Anita Lečei, prof. Preschool Education, PhD student of Early Learning \\ Univerza na Primorskem Pedagoška Fakulteta Koper \\ anita.leceiŽ gmail.com \\ Jurka Lepičnik Vodopivec, PhD, Univerza na Primorskem Pedagoška Fakulteta Koper \\ jurka.lepicnikŽp ef.upr
}

\section{SUMMARY}

To track social trends as well as new scientific discoveries in the fields of pedagogy, psychology and methodology is a prerequisite for a quality work and fair attitude towards the profession. Curriculum as the foundation of the educational process, appears in several forms in kindergartens. In addition to explicit (visible) practices of the pedagogue, we can find the so called „hidden curriculum“, which contains socio-emotional aspect of the educational groups. The concept of hidden curriculum is tied to implicit theories of the pedagogues, and it includes personal theories about value system, knowledges and expectations about nature and development of a child, and goals of education and views of appropriate means of achieving the goals. The William Glasser's Choice Theory explains human behavior is motivated by need to fulfill four base needs; need for love, power, freedom and fun. Comparing veiws and teachings of Choice Theory and opinions of the selected renowned pedagogues, we can find the same principles in implicit theories. Implementation of the established opinons of Choice Theory enriches the choice of pedagogical approach to early learning, and with it's strategies od education helps padagogues in educational methods.

Keywords: Implicit pedagogical theories, hidden curriculum, Choice Theory

\section{INTRODUCTION}

Today's modern era brings new challenges and changes that are fast and diverse. One of the fundamental and therefore most important and most difficult task of any society, contemporary included, remains to raise a child as a new member of the community to which he belongs. This important task of educating a child as an individual, with all the qualities required of him in the environment, is not only the right and obligation of the family the child belongs in biologically, but today this activity of education is imposed to wider community consisting of institutions such as kindergartens, schools, sports clubs, playrooms, etc.. Institutionalized education, as opposed to the family education (with a predominant biological and emotional connection among community members) is being done by employees who are professionals, and who are qualified for jobs of educating the children. In the kindergartens these are educators, professors and more recently masters of a degree and even PhDs. 


\section{THE PROBLEM, OBJECTIVES, TASKS AND METHODS}

The problem to which we refer in the submitted paper is discussing the possibility of a wider introduction (education) of teachers with Choice Theory, by William Glasser, in order to improve the pedagogical practices of educators. What encouraged us on the choice of this theme was the knowledge of Choice Theory by William Glasser, and experience in using it in working with children.

The primary goal of the work is to indicate which elements of the Choice Theory can be used in working with preschool children, and the secondary (which is linked to the previous) is how can it be incorporated into the education or professional training of educators and other professionals in preschool institutions.

The main task of the research is to compare the findings of scientific researches and scientific texts dealing with the hidden curriculum in kindergarten and implicit theories of educators, with elements of Choice Theory.

Secondary tasks are:

- To indicate the development of the profession of educators in institutional education.

- To define terms such as curriculum and hidden curriculum and teachers' implicit theories.

- To introduce the Choice Theory as a new approach to understanding personal psychology.

The paper is based on a descriptive, comparative and historic method of unexperimental educational research.

The descriptive method is used while describing the condition and characteristics of the hidden curriculum and the implicit theories of educators, as well as to describe elements of Choice Theory that can be used in the educational process.

The comparative method was used in the chapters: "Implementing of the Choice Theory in implicit theories of educators" and "theory of choice in the education of pre-school children."

The historical method was used while describing the development of the profession of educators, as well as the temporal development of certain terms related to the topic of the work (curriculum, the hidden curriculum, implicit theories, Choice Theory).

\section{PROFESSION OF THE EDUCATORS}

Serdar (2013) states that persons who have first begun to work in preschool education in Croatia, gained their education outside the Croatia. Women's Prep (Teacher Training College) Sisters of Mercy, founded in 1848, became public in 1851. She had two courses including one preparation course in the beginning. With that school there was a special course for training of nursery school (kindergarten's early name) teachers. On the basis of the law on the organization of elementary schools and prep schools from 1874, Department of Education and Religious Affairs in 1878 issued an order for the organization of a special course for educating of the preschool. Courses lasted for one year and were established in the schools for the training of the woman teachers. In 1880 a permanent, one-year course for Kindergarten teachers was established as a part of the women's prep in the monastery of the Zagreb and course content was determined by the structural statute for teacher schools.

Today, professional stafl in kindergartens acquire their professional competencies in high schools and universities, and the rapid pace of changes in society requires further, continuous monitoring of new knowledges in the field of pedagogical, psychological and methodological research.

"Educator's fundamental role is no longer the transmission of knowledge, but rather a complex developing of sensitivity and awareness for sustainable development. Educator becomes the coordinator, organizer and moderator of the group. He knows how to direct and organize independent and collaborative work of children in contacts with various sources of information and the practical actions in kindergarten "(Lepičnik Vodopivec, 2013/2014, p. 17) 
Speaking of characteristics, expected from good educators for other educators to have, Turnšek (2008) states during comparation of the expectations in Slovenia and Finland, that the Slovenian teachers stated traits as kindness, creativity and to be able to train children for their cooperation and participation. In the same time Finnish teachers prefer: tolerance of the educator, success in cooperation with parents and the ability to use theoretical knowledge in practice. Based on that research Turnšek (2005) emphasizes that the cultural group affiliation determines (rather than level of education and years of service) the beliefs and attitudes of educators.

The differences are evident between the Finnish and Slovenian teachers, in attitudes concerning democratization of kindergartens (the hidden curriculum, the attitude towards immigrants and their cultural rights) as well as the objectives and tasks of kindergartens and desirable characteristics of children and educators. Cultural differences with respect to education are manifested as the contrast between the postmodern conception of "New Collectivism", ie, the modern concept of individualism, and the transition emphasized education. The so-called "lands of plenty" with a long democratic tradition, including Finland are returning to the interdependence between individuals and communities, respecting cultural differences and individual rights. While Slovenia as a transition state with a neo-liberal elements of social development prefers successful achievement of an individual in the competitive oriented society, with an emphasis on the material.

Almost all experts for preschool education agree that the role of educators is of fundamental importance for the effectiveness of preschool programs. Children who are more encouraged by educators, persist longer in the activities, and are more independent. Personality of the educator: organization of space to play, offering appropriate resources, materials and activities, and directing the child's transition from one activity to another, are connected (Bahovec, Kodelja, 1996).

Particularly important is the ability for a friendly rapport, trust, responsibility for others, communication skills, empathic involvement, gradualism and complexity, authenticity and service education. (Tunjić, 2009)

In a study (Clare, Lapić, Šimić- Šašić, 2011), which was attended by 92 educators, educators were assessing responsibility and social reputation of their business as well as pleasure with a variety of its aspects. The results showed that the tested educators held their job responsible, and the social reputation of their profession unsatisfactory. They are most satisfied with their job with the kids, relationships and working hours, and least satisfied are with the social reputation of the profession, the number of children in groups and wages. In conclusion, the authors state that the support for training and advancement, physical conditions of work, the number of children in groups, social reputation of the profession and salaries - all aspects of work that should be worked on to reduce job dissatisfaction and increase the efficiency of an educator, and together with it a positive impact on development of children.

Exploring the professional development of educators in terms of their professional and personal expectations, Hmelak and Lepičnik Vodopivec (2013) on 616 Slovenian and Croatian students of preschool education and educators of preschool children, determine that respondents mostly want to participate in vocational training, and are interested in regular reading of the scientific literature, and interested in appreciation of their own initiatives.

\section{HIDDEN CURRICULUM AND IMPLICIT THEORIES OF EDUCATORS}

Using of the word curriculum appears in the field of education in the 18th century, in England, in conjunction with study programs. (Bahovec, Kodelja 1996) Contemporary understanding of the curriculum as the basis of the educational process appears in several forms that are present in kindergartens: the official curriculum (prescribed), the real curriculum (realization), the formal curriculum (time of regular educational obligations) and the so-called informal, hidden curriculum (other activities that take place in preschools). (Kelly, 1989; Colin, 1992; Graovac, 1996: Lepičnik Vodopivec, 2013/2014) 
"The hidden curriculum is a term that refers primarily to the social-emotional aspect of educational group ...... The important place in the hidden curriculum belongs to the personality of the educators. It depends on what kind of style of education is used, what kind of the communication will exist in child-parent-educator triangle, and what situation for learning will be organized. "(Lepičnik Vodopivec 2013/2014. P 17)

Implicit theories include expectations and predictions of the educators about the possibilities of learning and child development, it affects the learning, development, and education of children. (Miljak, 1993, in: Turnšek, 2008) Another definition that explains the implicit theories says that it includes personal, private theories about the personal system of values, knowledge and expectations about the nature and development of the child, and the objectives of education and attitudes about possible and appropriate means of achieving these goals derived from them. (Pesic, 1987, in: Turnšek 2008) Different names for similar concepts are also: Practical theory, practical philosophy, personal practical knowledge, personal strategies and subjective theories of educators. Turnšek (2008), in conjunction with subjective (implicit) theories raises the question of to what extent are pedagogical workers aware of their structures and theories, and adds that most theorists think that the subjective theory of pedagogy include both explicitly expressed positions (values, explanations) and implicit assumptions which we can infer indirectly through behavior. The question which level is prevailing with the individual remains.

Turnšek (ibid) compares the concept of the subjective theories and the concept of hidden curriculum, stating that the two terms coincide but do not overlap at large. Both cases are the implicit assumptions, unaware influences which mark everyday life and learning of children in institutions. The concept of the subjective theories applies not only to unconsciously and implicitly but also includes the concept of personal theories and attitudes that educators verbalize and are reflected in the explicit assumptions of their decisions and behaviors in pedagogical situations. Subjective theories of educators on children's nature, role and tasks of preschool institutions are not only an integral part of the hidden curriculum of the institution but also codetermine it.

The author Bregar Golobič (1996) states that the rules and expectations of kindergarten as an institution are part of a wider network of social (social) structure. She believes that the disclosure of the impact of hidden curriculum means the disclosure of its social structure, not a lack of professional competence or personal self-will of the educator. "

Some studies show that the (auto) reflection of personal assumptions of educational work, is particularly successful in the case when the educator faces his conduct, standards and educational assumptions with the views and arguments of education of other countries. Studies of other cultures in addition to documenting the diversity of human expectations, serve as a cultural critique of ourselves. (Turnšek, 2008) Given the volatility or stability standpoint and subjective theories with the educators, the author states that the two sets of research questions prevail:

- Can attitudes (implicit theories) be changed, and if not, what strategies we use to preserve cognitive compliance and the associated stiffness.

- Under what conditions there might be changes, and which features of cognitive personality traits and characteristics of social and cultural contexts allow changes.

In connection with this issue among theorists prevails the claim that the persistence or striving for immutability are significant features of implicit theories. However, the author also states that according to the theory of social representations (Moscovici, 1961; Ule, 2004 in: Turnšek, 2008), social values as the interaction and communication between people have a decisive influence on cognitive processes, and that within this framework new values are made. 


\section{WILLIAM GLASSER'S CHOICE THEORY}

One of the most prominent psychiatrists in the world, known as the founder of Choice Theory and counseling or psychotherapeutic methods - Reality Therapy. W. Glasser was the founder of the William Glasser Institute in California, an international organization that deals with the application of Choice Theory, Reality Therapy, organization "Quality school "and" quality management "- by the principles of Choice Theory.

Choice Theory is set versus external control psychology that explains human behavior as response to an external stimulus (stimulus-reflection of). "The operating premise of external control psychology that applies world read: punish people who make wrong, so they do what we say it is good; Then reward them to continue to do what we want to. "(Glasser, 2000, p. 15)

Choice Theory argues that everything we do is behavior (action) that almost all behaviors are chosen, and that we are driven by our genes (and internal motivation) to satisfy five basic needs: survival, love and belonging, for power, for fun and freedom. The most important is our need for love and belonging, since we achieve closeness and connection with the people we care about. With that closeness, we build relationships with people, and according to Choice Theory, it's a key factor of a happy life. (Glasser, 2000)

What happens when some of our basic needs are not met, says Modrić (1999) explaining, when some of our needs are not being met, we act as a control system. This means that you are constantly comparing what we want to achieve with what we have achieved and behave in accordance with the intention to reduce the difference between the two. Mathematically speaking frustration is precisely the difference between what we want (world of quality in our minds) and what we have (the way we see the situation in the world around us). As our desires are more important and more significant, frustration will be stronger when we do not get the desired.

Our needs can be satisfied only by satisfying specific image (ideas, concepts, desires) in our inner world (the world of quality). In this world, everything that we are sure it is worthwhile exists. "Even before birth we begin to create something that is best described as a sticker album in our minds that we begin to fill with detailed thumbnails of what we want. All our life we spend in completing such an album. "(Glasser, 1997, p. 21) "Our world of quality is the core of our life, because that is our immediate motivation - that's what we watch when we are frustrated. If there are no images that would satisfy the need, we need to try to create; our needs can't be met directly. "(Glasser, 2001, p. 81) The author further suggests that the only way that we can remove the thumbnails to replace them with new ones, which will be able to meet the same basic needs.

"The difference in what people want and notes that receives (input) at any time, is the current source of specific behavior of the individual." (Wubbolding, 1999, p.9)

Our system of behavior works all the time in order to meet our needs. "Our behavior consists of four parts which together make up each of our behaviors. These four parts are: the action; opinion; feelings and physiology. (Sullo, 1995, p. 71) All of our efforts in life boil down to the fact that, with mentioned, entire (indivisible) behavior, we strive to conduct the outside world as we perceive it - change into the world that would be as close to our inner world of quality. Immediately we can only monitor the opinions and activity, and the feelings and the physiological processes only indirectly through the activities and opinions. (Glasser, 2000)

How to build your relationships with close people? Glasser (2000) lists seven "caring habits" which cherish the relations: support; encouragement; listening; acceptance; belief; respect and negotiation (the differences). Further, Glasser talks about the seven "deadly habits" which spoil the relations and which should be avoided in relationships: criticism; blaming; grouse; regret; threats; punishment; bribery (rewarding so we could control). The importance of the relationships according to Glasser can be seen in one of the basic axioms of Choice Theory which reads: "All long-lasting psychological problems are relationship problems." 
People meet their needs through other people. Through the prism of Choice Theory, Perry Good (2009) in his definition of intimacy with another person states that closeness is when you meet her needs and she meets yours. As the most important relationships for each individual Glasser (2000) states: Partnership; parenting; educational; labor-business and friendly relationships.

The process of creation is constantly present in our overall behavior. Since we constantly create our behavior, whenever our behavior helps in gaining increased control (over a frustrating situation) we store it in the system behavior as organized and ready to use in a situation where it could work. (Glasser, 1997)

Choice Theory has several forms of use in the personal life of the individual (Choice Theory), Reality Therapy (psychotherapy), Cooperative conduct (business relationships) and Quality School (educational activity)

\section{IMPLEMENTATION OF CHOICE THEORY IN EDUCATOR IMPLICIT THEORIES}

Modern society needs individuals who will be able to adapt to the continuous changes and requirements, by expanding their (professional) skills, adding to it, building on the experiences from practice. It is precisely such individuals that are in need among the ranks of current and future educators of young children. (Hmelak, Lepičnik Vodopivec, 2013)

The acquisition of new knowledge (such as knowledge of the theory of choice) in working with preschool children, caregivers can get not only during the acquisition of their professional competence, but also later parallely with the work, in seminars or training. Choice Theory has several stages of education: "Basic Intensive week", "Basic practicum", "Advanced Intensive Week","Advanced Practicum", "Certification Intensive Week". The certificate that is obtained after two years of education gives the student the authority to use knowledge from Choice Theory in their primary profession. Continuation of training in Choice Theory is achieving position as counselors or psychotherapists of Reality Therapy (Reality Therapy is the use of Choice Theory in psychotherapy). Education in Choice Theory is available to certain 'helping' professions (teacher, psychologist, social worker, physician, educator, teacher ..) Financing of education depends on the good will or capability of employers.

Sullo (1995) on the internalisation of knowledge, guides educators and professional staff who work with children, to check the effectiveness of the described on themselves, by implementating attitudes of the Choice Theory so they could speak from their experience (from direct knowledge), not only from book knowledge (what choice Theory is called indirect experience). People rarely relinquish their behavior, because they feel it will help meeting their needs (for love, power, freedom and fun).

Let's consider the creation of implicit theories among educators. Turnšek (2008) assumes that the behavior and actions of educators (and other professionals) in concrete pedagogical situations, are associated with their "thought world" and the way of constructing reality. She says that theoretical knowledge that students receive at colleges are first "stock of knowledge" that an individual interprets and transforms in accordance with the earlier, subjective assumptions, attitudes, values, preferences and personal theories about what the task of the kindergarten is, how the child learns, what is the role of adults and so on. This attitude of already cultivated attitude toward education (even before students go to the teachers colleges) is supported by Glasser (2000) claiming that the reason why we see reality differently than the others, is the other important world in us, unique to each of us called a "world of quality".

Why everyone sees a different quality, is explained by Pirsig (2005) contemplating on the subject of quality, he states that the quality is faceless, irregular and indescribable. Shapes we give to quality, are only partially dependent on the quality itself, and are partly dependent on a priori images that we've accumulated in our memory. We are continuously trying to find something analogous to our previous experiences in the event of quality. Not to do so would render us unable to act. Our language and whole culture are built within these analogies. As the 
reason why we see the different quality, author emphasizes that the reason is that we approach it with different sets of analogies. People differ when it comes to quality, but not because the quality is different but rather that people are are different in terms of experience. Person's choice of quality defines them.

Wubbolding (1998) describes our world of knowledge as a part of our mindset calling it "the warehouse of notes." "It contains the memories of all our experiences: pleasant and unpleasant, desirable and undesirable. It contains memories of places, events, ideas and so on. A small part of this is our collection of desires, or "the world of what we want," of all the images we perceive as high quality ... These observations are unique to each individual and give meaning to the outside world . "(ibid, 1998, p. 54)

The answer on how to implement, tested and proved educational values in implicit theories, with the educators could be given by Bornes Boffy (1995) in his instructions how to rebuild some opinions that are not acceptable to us personally or for our profession. The opinions of the two authors agree in stating facts that most of the concepts, assumptions, principles and beliefs that we use in life (and work with children) derive from our families, and date from the early stages of development. Bornes Boffy (ibid) states that in such case we need to learn new behaviors to meet our needs in a different and more acceptable (to themselves or others) way. Bit of such a process is the creation of a new world of quality through new frames in the same world. Then we need to start behaving in a new way, in order to start feeling in a new way. "Strengthening the new settings and beliefs are similar to training a new muscle ... As soon as you start to behave in accordance with your vision, you gain control of your progress and see what is taking place." (Ibid, p. 65) The role of the mentor and proper mentoring in such process, is emphasized by the fact that it is useful to connect with others who have undertaken similar changes in their life, as they will help the individual to ask the right questions in order to see to where they want to be.

Turnšek (2008) reflects on the role of mentors in the educational process, noting that many studies are drawing attention directly or indirectly, to an important but not yet explored role of leadership, ie, directing the kindergarten. The author draws attention to the publication "Leadership in the area of preschool education" (Nivea and Hujala, 2002, in: Turnšek, 2008), which confirms that the (improper) conduct is the weak point of the modern European kindergartens. Studies show that adequate supervision, quality mentoring and other forms of guidance, contribute significantly to raising the level of expertise in educational work with the educators.

"The decisions that the practitioner should adopt in the immediate educational practice, being a very interdisciplinary and multidimensional process, are defined by his sensitivity for identifying, assessing, understanding and appropriate response to the current moment, and selecting appropriate strategies." (Segud, 2011)

Glasser (2000) states in the Choice Theory so-called "seven caring habits": encouragement, belief, support, respect, acceptance, negotiation and listening, and thereby defines appropriate strategies both in the educational process, as well as in relationships. At the same time, he lists the seven "killer" habits that are the destroyers of the relationship and not an adequate choice of strategy behavior: blaming; regret; grouse; threats; bribery; criticism and punishment.

Turnšek (2008) concludes that the common assumption of past researches is reflected in defining attitudes as a major (causal) leverages of human behavior. In contrast, numerous studies show that the process is reversed. Changing behavior, eg, the introduction of new pedagogical approaches, the implementation of a new theoretical model, contributes to the transformation of the existing views and understandings. Glasser (2000) talks about the overall behavior, which consists of four inseparable components: the activity; opinion; feeling; physiology. And although all four components are always present when you select the overall behavior, you only have direct control over your actions. So both authors emphasize behavior change (activity) as a starting point for changing opinions and attitudes, thereby improving attitudes, views and understanding (which makes an implicit theory of educators). 
The theory of social representations (Moscovici, 1961, Ule, 2004 in: Turnšek 2008) talks about setup of social values as the interaction and communication between people having a decisive influence on cognitive processes, considering that new values are created within the frameworks, which coincides with the Choice Theory where people (if there are no matching behavior in their behavior warehouse. ) create new behaviors to align with external information, satisfying one of its four current needs.

\section{CHOICE THEORY IN EDUCATION OF PRESCHOOL CHILDREN}

Glasser, like many of his colleagues, often speaks on education, stating that teaching is probably the hardest job in the world. Great importance is given to the way in which the educational processes are conducted proposedly by Choice Theory. His theory is placed in special programs and policies, which (if well-implemented by schools) give recognition and the right to bear the name of "quality education". If we remember previously stated views on the quality, we can agree with this statement: "It is hard to find a definition of quality education that would be generally applicable. Although quality education can not be defined, the quality can always be recognized. "(Glasser, 2005, p. 16) As Choice Theory considers healthy relationships as a basis, a conclusion is that successful learning is based on a positive strong relationship between teacher and student. (Glasser, 2001) As the basic tenets of "quality school", author mentions the: quality work; self-evaluation; agreement and cooperation; cooperative conduct; intrinsic motivation; collaborative yield; success; help; and cooperative learning.

As the fundamental goal of education Tunjić (2010) cites the growth and full development of the person, considering interpersonal relationships as an important element of education, because it builds educational activities. "Young people are not really as sensitive to the complexity as they are the impersonality and inconsistency of the educators. They expect closeness and understanding from adults."(Ibid, p. 238)

Sullo (1995) states that even very young children can learn the essence of the Choice Theory and learn that their happiness is a direct product of their choice. When choosing bad behavior Choice Theory prefers discipline and not punishment. A child with inappropriate behavior shall be suspended from the group but not penalized. The child must devise a plan for appropriate behavior in order to re-join the game.

Author believes that it is appropriate asking the two year old to think, and to help him perceive the connection between their behavior and choices to what is happening to him, and the moment of happiness. At the same time two year old can not independently plan effective behavior and he needs help to create a plan. The author states that the aim is to work with young children to help them develop a greater range of effective behavior, which will meet their needs in a socially acceptible way.

Knowledge of Choice Theory also allows educators to develop better relationships among children, by teaching them social skills. Socio-emotional development can be stimulated by introducing so-called "seven caring habits." The game, as the closest to the content and favorite activity, is possible to be enriched by the appropriate games in which children learn how to "care" about relationships and friendship. It is advisable to teach children about: encouraging (in fan activities in sport), encouraging contacts: (cuddling the kitten); belief (in games when the mutual success depends on the trust and belief in the partner, for example, in the game: the pilot and controller, guides and blind); support (games in which partners support and adhere to each other to success: cat and mouse, back to back); respect (to teach children respect for other people's space in the game: hawk and chickens); acceptance (to teach children acceptance of diversity: a mirror, like his friend); bargaining (learn negotiation skills in the game: the mother goes to the station); listening (to play the game and enjoy the success of an individual or group depends on listening to each other: a broken phone, paraphrase, zvončar). Also, children may be presented with the consequences of poor selection of behavior in relationships (so-called "seven deadly habits"). Becoming aware of the bad consequences of choosing the same, and talking about the 
different choices gives children the opportunity to choose new behaviors that will build and not tear down social network and relationships with peers.

Perry Good (1993, p.89) states that one of the ways to make the time you spend with the children important, is to participate in specific activities of interest to children: "To stay on the thumbnails of your child as a person who meets their needs You must stay involved. .... Involvement $=$ time + importance. To truly be involved with people means spending time with them and talk about things that are important to them."

We have found that in the hidden curriculum and the implicit theories of educators, the quality of their educational practices is reflected. In this context, let us remember the quote (Lepičnik Vodopivec, 2013/2014, p 17) " The important place in the hidden curriculum belongs to the personality of the educators. It depends on what kind of style of education is used, what kind of the communication will exist in child-parent-educator triangle, and what situation for learning will be organized." Let's mention the attitude of one of well-known experts in the field of preschool education (Miljak, 1993, in: Turnšek 2008), which reads: "the implicit theory encompasses the educator's expectations and predictions about the possibilities of learning and child development, it markedly affects the learning, development, and education of children"

Šegud (2011) refers to the same subject saying: "Decisions that a practitioner should decide in the immediate educational practice, as a very interdisciplinary and multidimensional process, are defined by its sensitivity for identifying, assessing, understanding and appropriate response in the current time, and a choice of the adequate strategies."

In the chapter "Choice Theory by William Glasser," we found that knowledge of the Choice Theory, we can identify and explain the actions of educators and their implicit theories. It's especially emphasised with Glasser's explanation on how to meet our needs five (p. 9) and the way they are (in this case educator) met. Our needs can be satisfied only by satisfying specific images (ideas, concepts, desires) in our inner world (the world of quality). In this world, everything worthwhile for us found it's place. The process of creation is constantly present in our overall behavior. Since we constantly create our behavior, whenever it helps in gaining increased control (over a frustrating situation) we store it in the system behavior as organized and ready to use in a situation where it can help. (Glasser, 1997)

Educating educators in the direction of knowledge and the use of knowledge of Choice Theory, can improve the quality of the work of educators in preschool. This attitude is confirmed by explanation Sullo (1995) states; that even very young children can learn the essence of the Choice Theory and recognize that their good fortune is a direct product of their choice. When choosing bad behavior Choice Theory prefers discipline and not punishment, noting that the goal of working with young children is to help them develop a greater range of effective behaviors, those which will help them meet their need in a socially acceptible way. Issues that could be stated concerning the topic of implicit theories of educators:

- How to define the characteristics of a good educator and a quality that distinguished him? In different countries and researches, we encounter different expectations. Speaking of characteristics, which educators themselves expect from a good educator, Turnšek (2008) compares the expectations in Slovenia and Finland, and the Slovenian teachers stated traits as: kindness, creativity and being able to train children for their cooperation and participation. In the same time Finnish teachers are more fond of : tolerance of educators, success in cooperation with parents and the ability to use theoretical knowledge in practice. We stated it (page 7) as a result of social and moral developments in these two different societies.

- Should we strive to equalize the hidden curriculum and the implicit theories at educators in this world of unification and globalization? Or should we accept pluralism of kindergartens in the segment of implicit theories of educators relying on their professional competence. Possible education in this direction should be left to educators, and ensure that such training is enough to choose, and that all are equally valued by the kindergarten.

- It could be explored what do kindergarten gain, and what is lost regarding the quality and credibility of attitudes where there are only one type of program across the institution conducted (eg: Waldor א kindergarten, Montessori kindergarten, quality schools, Step by Step 
program) or where the results of different methods of education in the same institution are checked (exploring the expectations of the community, parents, teachers, children).

\section{CONCLUSION}

Exploring the opinions and conclusions of teachers that are engaged in research teaching practices of educators in preschool and Glasser's Choice Theory, we can see an unanimity in a way people (in our case educators) build their views and their values that lead them through life and their work. We can observe the same conclusions regarding childhood as a period of construction of "world of quality" as a scheme one later compares their attitudes towards children and positions in the profession, and which are characterized by implicit attitudes with the educators. (Jalongo, 2002, in: Turnšek 2008) argue that in our biographies memories and childhood experiences take special place, as the most important time for the process of constructing the fundamental concepts concerning the education of children, in the same time impacting current beliefs, values and behaviors. Let's point out the matching of several theses, and conclusions that a change of attitudes changes our behavior (and not vice versa). For the objective of this thesis we stated: Marking of the elements of the Choice Theory which can be used in working with preschool children. Based on many years of Choice Theory usage in kindergartens, primary and secondary schools, through curriculums of "quality schools" the settings of Choice Theory were integrated in practice. In the chapter "The theory of choice in the education of pre-school children" we stated which settings can be implemented, while in the same time explaining how they can be transmitted in pedagogical practice. This means that education of teachers in the direction of introducing the Choice Theory can reasonably be recommended. As a second objective we pointed out: how can Choice Theory be included in the training or professional development of educators and other professionals in preschools. On most teaching faculties in Slovenia and Croatia, as well as colleges of education, the practice of exploring Choice Theory was introduced, so that future practitioners can get the first information on the specific educational practice, represented by the Choice Theory, during the regular schooling for their profession. In addition to this information, we recommend professional development of teaching stafl with 2.5 years of education, which acquires them the right to use Choice Theory knowledge in their primary profession.

Education is regularly organized by IRT - Institute for Reality Therapy in Slovenia, HURT - Croatian association of reality therapists in Croatia and EART- European Association for Reality Therapy in Europe.

The value of Choice Theory knowledge is explained by the fact that the Choice Theory as an important education is recommended (and funded) for employees of the Croatian social welfare centers.

The questions that we can still consider: What contribution can the knowledge of Choice Theory implicit theories of educators and the hidden curriculum of kindergarten bring:

1. On a personal level of educators, as persons?

2. At the kindergarten level, as educational institutions?

3. At the professional training level?

1. Introduction of educators to Choice Theory offers an explanation for their own and others actions including the children's. It allows them the knowledge about what motivates children and them personally, that is, what is children's and their world of quality. Next, what is it that I can do to change my attitudes and thus my implicit theories. Education in Choice Theory is not therapeutically oriented, but the knowledge of it explains professional and personal life problems to educators. By getting to know the elements of the Choice Theory, educators change their previous beliefs based on the so-called old psychology of external control "My behavior is a response to the circumstances" in the conviction based on the new psychology of Choice Theory "My behavior is my choice in certain circumstances." (Hurt, 2009) 
2. In particular we emphasize the Choice Theory thesis of the importance of the relationships by saying "Attitudes are my behavior, with which i can fulfill my needs next to other person." Greater explanation of such a paragraph is found in the difference between the attitude of psychology of external control ("My responsibility is to the title of my role, to achieve that you act the way I want, think is properly, and your responsibility is that you act accordingly" and Choice Theory attitude "it is my duty (liability on account of my role) to supply you with all necessary information, and what will you do with them is your choice for which you suffer the consequences." (ibid, 2009) With adoption of such an attitude and behavior (as elements of the hidden curriculum) educators develop tolerance in relationships with children for whom they are responsible as adults. At the same time, they gain knowledge about the importance of good relations for adequate pedagogical and educational activities, as well as the right to choose their behavior. The expansion of such a spirit in kindergarten, educators are developing in the direction of postmodern philosophy and postmodern approach to education which emphasizes a shift from education as the exclusive responsibility of adults to children's development, to the practice of consultation with children, through construction of educational process.

3. Professional training in the direction of Choice Theory gives the new knowledge at the highest level of the new psychology changing personal and professional life quality of educators. In HURT in Croatia and in IRT in Slovenia, people can obtain a high quality partner in the education of children who not only provides basic training but subsequently allows educators to actively participate in the implementation of Choice Theory in their work, as well as the presentation of the same in terms of participation in seminars and scientific conferences organized in order to study and improve teaching practice guided by the idea of Choice Theory. Regular meetings of Choice Theory practitioners in pedagogical frameworks are quality school meetings -"KVAS̆" where pedagogical staf؟ who work with children at all ages (kindergarten, primary and secondary) are presenting the projects and the results of their teaching practices in order to enhance their professional competence.

\section{REFERENCES}

1.) Bahovec, D. E. I Kodelja, Z. (1996). Vrtci za današnji čas. Ljubljana: Center za kulturološke raziskave pri Pedagoškem inštitutu in Društvo za kulturološke raziskave.

2.) Barnes Boffy, D. (2009). Nanovo se stvoriti. Zagreb: Alineja.

3.) Bregar Golobič, K. (1996). Vrtec pod gradom: vrtec z evropskim delovnim časom drugače v vrtcu. Ljubljana: Center za kulturološke raziskave pri Pedagoškem inštitutu in Društvo za kulturološke raziskave.

4.) Čagran, B. Ivanuš Grmek, M. Fošnarič, S. Pšunder, M. in Ladič, J. (2013). Priročnik za izdelavo zaključnega dela za študijske programe 1, 2 in 3. stopnje. Maribor: Pedagoška fakulteta.

5.) Glasser, W. (1997). Teorija kontrole. Zagreb: Alinea.

6.) Glasser, W. (2000). Teorija izbora. Zagreb: Alinea.

7.) Glasser, W. (2001). Realitetna terapija u primjeni. Zagreb: Alinea.

8.) Glasser, W. (2005). Kvalitetna škola. Zagreb: Alinea.

9.) Hmalek, M. Lepičnik Vodopivec, J. (2013). Pričakovanja vzgojiteljev predšolskih otrok, vezana na njihov profesionalni razvoj. Revija za elementarno izobraževanje, 6 (2-3), 6377.

10.) HURT, (2009). Početni intenzivni tjedan edukacije iz teorije izbora, realitetne terapije i suradničkog vođenja. Zagreb: HURT.

11.) Klarin, M. Lapić, L. Šimić - Šašić (2011). Percepcija odgovornosti, društvenog statusa i zadovoljstva poslom odgajateljica. Magistra Iaderna 6 (6), 55- 68.

12.) Lepičnik Vodopivec J. (2013/2014). Vidljivi i skriveni kurikulum odgoja i obrazovanja za održivi razvoj. dijete vrtić obitelj, 74, 16-17.

13.) Modrić, N. (1999). Lutka vodič. Zagreb: Nevenka Modrić. 
14.) Perry Good, E. (1993). Kako pomoći klincima da si sami pomognu. Zagreb: Alinea.

15.) Perry Good, E. (2009 ). U potrazi za srećom. Zagreb: Alinea.

16.) Pirsig, R. M. (2005). Zen i umjetnost održavanja motocikla. Zagreb: Zagrebačka naklada.

17.) Serdar E. (2013). Počeci institucionalnog predškolskog odgoja u Hrvatskoj. djete, vrtić obitelj, 71, 4-6.

18.) Sullo, R. A. (1995). Učite ih da budu sretni. Zagreb: Alinea.

19.) Šegud, M. (2011). Inicijalno obrazovanje odgajatelja i profesionalni razvoj. Pedagoška istraživanja, 8, (2), 259-269.

20.) Tunjić, N. (2010). Lik odgojitelja u Novom zavjetu. Napredak 151(2), 236-253.

21.) Turnšek, N. (2008). Subjektine teorije o otroštvu in vzgoji. Ljubljana: Pedagoška fakulteta Univerza v Ljubljani.

22.) Wubbolding, R.E. (1998). Kako razumjeti realitetnu treapiju. Zagred: Alinea.

23.) Wubbolding, R. E.(1999). Realitetna terapija u radu s djecom. Zagreb: Alinea. 